\title{
KOMBINUOTOS ANESTEZIJOS POVEIKIS INKSTŲ FUNKCIJAI PO VAINIKINIŲ ARTERIJŲ ŠUNTAVIMO, NAUDOJANT DIRBTINE KRAUJO APYTAKĄ
}

\author{
Agnė Kaunienė, Aistė Urbonaitė, Tadas Lenkutis, Edmundas Širvinskas, Milda Švagždienė \\ Lietuvos sveikatos mokslu universiteto Medicinos akademija, Lietuvos sveikatos mokslu universiteto \\ Medicinos akademijos Širdies, krūtinès ir kraujagysliu chirurgijos klinika
}

Raktažodžiai: aukšta epidūrinė anestezija, ūminis inkstų pažeidimas.

\section{Santrauka}

Tyrimo tiklas išsiaiškinti bendrinès anestezijos su aukšta epidūrine analgezija (TEA) ir bendrinès anestezijos (BA) poveikị inkstų funkcijai po vainikinių jungčiu suformavimo (VAJO) operacijos, dirbtinès kraujo apytakos (DKA) sąlygomis.

Medžiaga ir metodai. I tyrimą itraukti pacientai (49 - 82 metų), kuriems nuo 2014 m. spalio iki 2015 m. spalio LSMUL KK Širdies, krūtinès ir kraujagyslių chirurgijos klinikoje buvo atliekamos VAJO DKA sąlygomis. Pacientai buvo suskirstyti i dvi grupes: BA, jai priklause pacientai, kuriems taikyta tik bendrine anestezija (inhaliuojamieji anestetikai ir i/v opiatai); ir TEA (vietinis anestetikas ir BA inhaliuojamieji anestetikai su $\mathrm{i} / \mathrm{v}$ opiatais) grupę, jai priklausè pacientai, kuriems operacijos metu taikyta aukšta krūtininė epidūrinè anestezija, kombinuota su bendrine anestezija. Tiriamiesiems pacientams tris kartus buvo daromas biocheminis kraujo tyrimas - prieš operaciją, pirmą parą po operacijos, penktą parą po operacijos. Vertintos kreatinino ir šlapalo koncentracijos kraujo serume perioperaciniu laikotarpiu, kurios atspindi inkstų funkcijos sutrikimą [2].

Atlikto tyrimo rezultatai. İvertinus prieš operaciją kreatinino koncentraciją TEA grupeje vidurkis buvo 93,3 $\pm 16 \mathrm{mmol} / 1$, BA grupejje - 95,3 $\pm 23,5 \mathrm{mmol} / 1$ ( $>0,05)$. Pirmą parą po operacijos kreatinino vidurkis TEA grupeje buvo 101,3 $\pm 19,3 \mathrm{mmol} / 1$, BA grupejje - 104,81 $\pm 37 \mathrm{mmol} / \mathrm{l} .(\mathrm{p}<0,05)$. Penktają parą TEA grupejje kreatinino koncentracija buvo 97 $\pm 14,3 \mathrm{mmol} / 1$, o BA grupejje - 103,7 $\pm 31,6 \mathrm{mmol} / \mathrm{l}$. $(p<0,05)$. İvertinus prieš operaciją šlapalo koncen- traciją TEA grupeje vidurkis buvo 4,2 $\pm 1,19 \mathrm{mmol} / \mathrm{l}$, BA grupeje 5,2 $\pm 1,7 \mathrm{mmol} / 1(\mathrm{p}>0,05)$. Pirmą parą po operacijos šlapalo vidurkis TEA grupejje $5,6 \pm 1,8$ mmol/l,BA grupeje $6,2 \pm 2,0 \mathrm{mmol} / \mathrm{l}$. $(\mathrm{p}>0,05)$.

Penktają parą TEA $4,7 \pm 1,3 \mathrm{mmol} / \mathrm{l}$, o BA $5,8 \pm 3$ $\mathrm{mmol} / \mathrm{l}(\mathrm{p}<0,05)$.

Tyrimo išvados. Palyginus abiejų grupių rodiklius, TEA grupejje pastebimas mažesnis kreatinino ir šlapalo koncentracijų kitimas, lyginant koncentracijas prieš operaciją, viena diena po ir penkios dienos po operacijos nei BA grupejje.

\section{Ižzanga}

Ūminis inkstų pažeidimas (ŪIP) yra viena dažniausiu komplikacijų, kurias sukelia dirbtinė kraujo apytaka (DKA) naudojama širdies operacijų metu[1-3]. ÜIP klasifikuojamas pagal sunkumą nuo sunkaus (kreatinino reikšmė nuo pradinio padideja $>3$ kartų), reikalaujančio pakaitinès inkstų terapijos (dializès), vidutinio sunkumo (kreatinino reikšmè nuo pradinio 2-3 kartus didesnè), iki lengvo ( kreatinino reikšmè nuo pradinio padidejja iki 1,5), pasireiškiančio nedideliu serumo kreatinino padidejimu pooperaciniu periodu [4]. Sunkus ŪIP po kardiochirurginių operacijų išsivysto maždaug 5 proc. pacientų, tai yra rečiau nei lengvas ŪIP (30 proc. pacientu), tačiau yra susijęs su ilgesniu pacientų hospitalizacijos laikotarpiu, didesniu sergamumu ir mirtingumu (15-30 proc.)[2].

Pastaraisiais dešimtmečiais pasaulyje nuolatos ieškoma būdų, leisiančių kiek įmanoma labiau sumažinti ŪIP po širdies operacijų dažnį. Vienas tokių būdų, sulaukiantis vis daugiau anesteziologų dèmesio - bendrinè anestezija kartu su aukšta epidūrine analgezija (TEA). Ivairių tyrimų duomenimis, šis anestezijos būdas pasižymi širdị ir inkstus apsaugančiu poveikiu, mažina kitų komplikacijų, pavyzdžiui, miokardo infarkto, dažnį ir mirtingumą[5,6]. Vis dèlto dèl TEA renoprotekcinio poveikio vis dar ginčijamasi, viena to 
priežasčių - iki šiol atlikti tyrimai nèra pakankamai didelès imties.

ŪIP kriterijai. Savo tyrime rèmėmès Ūmaus inkstu pažeidimo organizacijos (angl. Acute kidney injury network) priimtais bendro sutarimo kriterijais, kuriuose ŪIP apibūdinamas kaip staigus (per 48 val.) inkstų funkcijos sumažejjimas, apibūdinamas absoliučiu ne mažesniu nei $26,4 \mu \mathrm{mol} / 1$ kraujo serumo kreatinino koncentracijos padidejimu ir (arba) reliatyviu, ne mažesniu nei 50 proc. kraujo serumo kreatinino koncentracijos padidejjimu ir (arba) diurezès sumažejimu (mažiau nei $0,5 \mathrm{ml} / \mathrm{kg} / \mathrm{val}$. šlapimo daugiau nei šešias valandas) [7].

Mūsų tyrimo tikslas - ịvertinti TEA renoprotekcini poveikị, taikant ši metodą aortos vainikinių arterijų jungčių suformavimo operacijų (VAJO) metu dirbtinès kraujo apytakos (DKA) sąlygomis. Siekème išsiaiškinti ir kẻlème hipotezę, kad TEA pagerins tiriamujų pooperacinę inkstų funkciją, kurią atspindi kraujo serumo kreatininas ir šlapalas.

\section{Darbo objektas ir metodika}

I tyrimą ịtraukti 50 pacientų, kurių amžius nuo 49 iki 82 metu (amžiaus vidurkis 65,4+/- 8,1 m.). Pacientai - 39 vyrai ir 11 moterų, - kuriems nuo 2014 m. spalio iki 2015 $\mathrm{m}$. spalio Lietuvos sveikatos mokslų universiteto ligoninès Kauno klinikų (LSMUL KK) Širdies, krūtinès ir kraujagyslių chirurgijos klinikoje buvo atliekamos VAJO DKA sąlygomis. Pacientai buvo suskirstyti ị dvi grupes: pirmajai grupei (BA) priklausè pacientai, kuriems taikyta tik bendriné anestezija (inhaliuojamieji anestetikai ir intraveniniai opiatai). I antrają grupę (TEA) paskirti pacientai, kuriems taikyta aukšta krūtininè epidūrinè anestezija, kombinuota su bendrine anestezija (nuskausminimas užtikrintas epidūrinè blokada vietiniu anestetiku ir miegas palaikomas inhaliuojamuoju anestetiku). Angiotenziną konvertuojančio fermento (AKF) inhibitorių ir trombocitų funkciją blokuojančiu preparatų vartojimas buvo nutrauktas priešoperaciniu laikotarpiu pagal klinikoje esamas rekomendacijas. Pacientams taikyta standartinè premedikacija 12 val. prieš operaciją (lorazepamas $1-2,5 \mathrm{mg}$ ). TEA grupès pacientams prieš bendrinès anestezijos indukciją, steriliomis sąlygomis pacientui ị epidūrinị tarpą tarp Th2 ir Th3 slankstelių ịleidžiamas epidūrinis kateteris (Perifix ${ }^{\circledR}$; B. Braun). I epidūrinị kateterị sušvirkščiama 2 proc. 2 ml. lidokaino tirpalo su adrenalinu 1:10000, siekiant ịsitikinti, kad kateteris ịvestas ne i povoratinklinį tarpą arba kraujagyslę. İsitikinus, kad kateteris tikrai įvestas ị epidūrinį tarpą, sušvirkščiama $6 \mathrm{ml} \mathrm{0,5}$ proc. bupivakaino. Bendrinès anestezijos indukcija abiejose grupėse atlikta naudojant fentanili, propofoli ir rokuroniumą,. TEA grupejje nuskausminimas palaiky- tas bupivakaino $0,125 \mathrm{mg} / \mathrm{ml}$ ir fentanilio $5 \mu \mathrm{g} / \mathrm{ml} \mathrm{4-6} \mathrm{ml} /$ val pastovia infuzija, miegas palaikytas inhaliuojamuoju anestetiku sevofluranu. BA grupèje, nuskausminimas užtikrintas fentanilio injekcijomis (suminè dozė 4-7 $\mu \mathrm{g} / \mathrm{kg}$ ), miegas palaikytas inhaliuojamuoju anestetiku sevofluranu. DKA sąlygomis atlikta širdies raumens apsauga kristaloidiniais St. Thomas tirpalais ( 84,0 proc.) arba drungno kraujo kradioplegija (6,0 proc.).

Pooperacinis nuskausminimas TEA grupejje užtikrintas pastovia bupivakaino $0,125 \mathrm{mg} / \mathrm{ml}$ ir fentanilio $5 \mu \mathrm{g} / \mathrm{ml} 4-6$ $\mathrm{ml} / \mathrm{val}$. pastovia infuzija, BA grupeje petidino arba morfino injekcijomis pagal poreiki.

Tiriamiesiems pacientams biocheminis kraujo tyrimas buvo daromas tris kartus: prieš operaciją, pirmają ir penktają parą po operacijos. Priešoperacinès šių inkstų funkciją atspindinčių rodiklių reikšmès lygintos su pooperacinèmis. Tyrimas atliktas gavus LSMU Bioetikos centro leidimą. Duomenų analizė atlikta su SPSS 20.0 paketu.

\section{Rezultatai}

50 pacientų susikirstyti į 2 grupes: BA grupeje 26 pacientai, TEA grupejje 24 pacientai. 11 moterų (22 proc.) ir 39 vyrai (78 proc.). Amžiaus vidurkis BA grupeje 67,5 \pm 7,4 m., TEA grupejje $63,2 \pm 8,5$ m. (p>0,05). Ivertinus prieš operaciją kreatinino koncentraciją TEA grupeje vidurkis buvo $93,29 \pm 16 \mathrm{mmol} / \mathrm{l}$, BA grupeje - 95,31 $\pm 23,5 \mathrm{mmol} / \mathrm{l}$ $(\mathrm{p}>0,05)$.

TEA grupejje pirmą parą po operacijos kreatinino ir šlapalo koncentracijos kraujyje statistiškai reikšmingai padidèjo (kreatinino koncentracijos vidurkis 101,3 $\pm 19,3$ $\mathrm{mmol} / \mathrm{l}$, šlapalo koncentracijos vidurkis $5,6 \pm 1,8 \mathrm{mmol} / \mathrm{l}$ ), o penktają parą po operacijos stebètas statistiškai reikšmingas abiejų rodiklių koncentracijų grịžimas ị pradinę reikšmę ( kreatinino koncentracijos vidurkis $97 \pm 14,3 \mathrm{mmol} / \mathrm{l}$, šlapalo 4,7 $\pm 1,3 \mathrm{mmol} / \mathrm{l})$.

Taikant BA, vertinant inkstų funkcijos rodikli kreatininą, pirmą parą po operacijos kreatinino koncentracijos kraujyje didejo statistiškai reikšmingai $(104,8 \pm 37 \mathrm{mmol} / \mathrm{l})$, o penktają parą po operacijos negrižo i pradinę reikšmę $(103,7 \pm 31,6 \mathrm{mmol} / \mathrm{l})$. Šlapalo koncentracija po operacijos pirmą parą didejo $(6,2 \pm 2,0 \mathrm{mmol} / \mathrm{l})$, tačiau statistinio reikšmingumo nestebèta, o penktają parą po operacijos grịžo ị pradinę reikšmę $(5,8 \pm 3 \mathrm{mmol} / \mathrm{l})$.

Palyginus TEA ir BA grupių inkstų funkcijos rodiklius, TEA grupejje pastebimas statistiškai reikšmingai mažesnis kreatinino ir šlapalo koncentracijų kitimas lyginant su rodiklių koncentracijomis prieš operaciją nei BA grupeje. ŪIP dažniau pasireiškè BA grupeje ( 9 pacientams, $(34,6$ proc.) nei TEA grupeje (6 pacientams, (25,0 proc.), tačiau skirtumas nebuvo statistiškai reikšmingas. 
BA grupeje DKA trukmè ir operacinis skysčių balansas buvo statistiškai reikšmingai didesni (atitinkamai 103,1+/$26,3 \mathrm{~min}$. ir $1966,9+/-838,7 \mathrm{ml})$ nei TEA grupeje $(87,8$ +/- 22,2 min. ir 1502,1 +/- 649,8 ml) (1-2 pav.).

\section{Diskusija}

Šis mokslinis tyrimas buvo atliktas siekiant išsiaiškinti skirtingų anestezijų poveiki inkstų funkcijai širdies

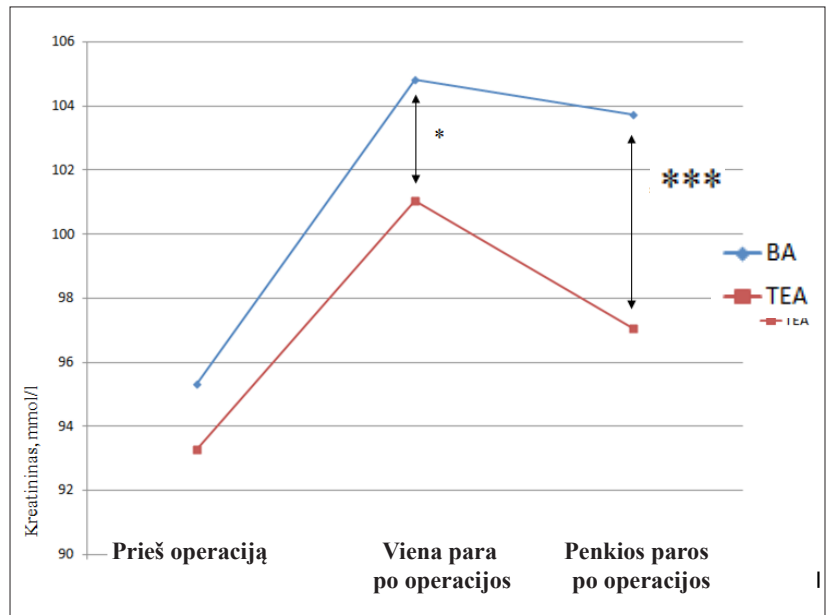

1 pav. Kreatinino koncentracijos kraujo serume pokyčiai BA ir TEA grupėse prieš operaciją, pirmą dieną po operacijos ir penktą dieną po operacijos

*-Pirma para po operacijos TEA grupejje kreatinino koncentracijos kitimas statistiškai reikšmingai mažesnis nei BA grupèje ( $p=0,041)$.

**-Penkta para po operacijos TEA grupéje kreatinino koncentracijos kitimas statistiškai reikšmingai mažesnis nei BA grupèje $(p=0,001)$.

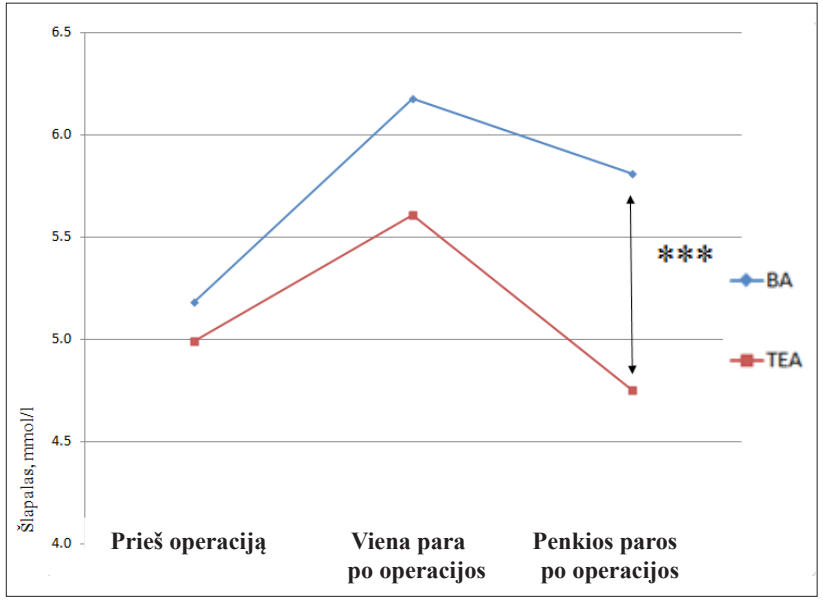

2 pav. Šlapalo koncentracijos kraujo serume pokyčiai BA ir TEA grupėse prieš operaciją, pirmą dieną po operacijos ir penktą dieną po operacijos

***-Penkta para po operacijos TEA grupejje šlapalo koncentracijos kitimas statistiškai reikšmingai mažesnis nei $B A$ grupèje $(p=0,03)$. operacijų metu DKA sąlygomis. Palyginus abiejų grupių rodiklius, TEA grupejje pastebimas mažesnis kreatinino ir šlapalo koncentracijų kitimas, lyginant koncentracijas prieš operaciją, viena diena po ir penkios dienos po operacijos nei BA grupeje. Tyrimo metu nustatyta, kad reikšmingai DKA trukmè ilgesne BA grupeje lyginant su TEA. Literatūros duomenys rodo, kad ilgesnė DKA trukmė yra vienas iš predisponuojančiu veiksniu ÜIP. DKA sukelia neuroendokrininès sistemos atsaką, kuris didina vazoaktyvių hormonu (epinefrino, noripinefrino, vazopresino) kiekį. Katecholaminų tiesioginis poveikis inkstams DKA sąlygomis yra sietinas su kraujo pritekejjimo sumažèjimu ir mažejančiu glomerulų filtracijos greičiu. Tačiau pastebėta, kad TEA metu, skirtingai nuo BA, yra slopinama simpatinè nervų sistema, dèl kurios sumažeja katecholaminų kiekis.[8] Mūsų atliktas tyrimas, vertinant kraujo serumo kreatinino koncentracijos kitimą atskleidžia, kad TEA taikymas širdies operacijų metu turi renoprotekcini poveikį. Šių tyrimų ir mūsų atlikto tyrimo trūkumas - maža imtis, kuri neleidžia daryti tvirtų išvadų dèl TEA renoprotekcinio poveikio [9].

\section{Išvados}

Taikant TEA, vertinant inkstų funkcijos rodiklius kreatininą ir šlapalą, pirmą parą po operacijos kreatinino ir šlapalo koncentracijos kraujyje didejo, o penktają parą po operacijos stebètas grịžimas ị pradinę reikšmę.

Taikant BA, vertinant inkstų funkcijos rodikli kreatininą, pirmą parą po operacijos kreatinino koncentracijos kraujyje didejo, o penktają parą po operacijos negrįžo ị pradinę reikšmę, šlapalo koncentracija po operacijos didèjo, bet penktają parą po operacijos grižo ị pradinę reikšmę.

Palyginus abiejų grupių rodiklius, TEA grupeje pastebimas mažesnis kreatinino ir šlapalo koncentracijų kitimas, lyginant koncentracijas prieš operaciją, viena diena po ir penkios dienos po operacijos nei BA grupejje.

\section{Literatūra}

1. Gude D, Jha R. Acute kidney injury following cardiac surgery. Ann Card Anaesth 2012;15:279-86. http://dx.doi.org/10.4103/0971-9784.101874

2. Ruel M, Mesana T, Chan V, Boodhwani M. Clinical impact of mild acute kidney injury after cardiac surgery. Ann Thorac Surg 2014;98:815-22.

http://dx.doi.org/10.1016/j.athoracsur.2014.05.008

3. Shaw A. Update on acute kidney injury after cardiac surgery. J Thorac Cardiovasc Surg 2012;143:676-81. http://dx.doi.org/10.1016/j.jtcvs.2011.08.054

4. Greisen J, Nielsen DV, Ryhammer PK, Sloth E, Jakobsen C-J. High thoracic epidural analgesia supplement seems to protect 
renal function, evaluated by serum creatinine changes, in cardiac surgery patients - a randomised study. Cardio Vasc Syst. 2013; 1:11.

http://dx.doi.org/10.7243/2052-4358-1-11

5. Bignami E, Landoni G, Biondi-Zoccai GG, Boroli F, Messina M, Dedola E, Nobile L, Buratti L, Sheiban I and Zangrillo A. Epidural analgesia improves outcome in cardiac surgery: a meta-analysis of randomized controlled trials. J Cardiothorac Vasc Anesth. 2010; 24:586-97.

http://dx.doi.org/10.1053/j.jvca.2009.09.015

6. Jakobsen CJ, Bhavsar R, Nielsen DV, Ryhammer PK, Sloth E, Greisen J. High thoracic epidural analgesia in cardiac surgery. Part 1: high thoracic epidural analgesia improves cardiac performance in cardiac surgery patients. J Cardiothorac Vasc Anesth 2012 Dec;26(6):1039-47. doi: 10.1053/j.jvca.2012.05.007. Epub 2012 Jul 6.

http://dx.doi.org/10.1053/j.jvca.2012.05.007

7. Mehta RL, Kellum JA, Shah SV. et al. Acute Kidney Injury Network: report of an initiative to improve outcomes in acute kidney injury. Critical Care 2007;11(2):R31.

http://dx.doi.org/10.1186/cc5713

8. Mao H, Katz N, Ariyanon W. et al. Cardiac Surgery-Associated Acute Kidney Injury. Cardiorenal Medicine. 2013;3(3):178199.

http://dx.doi.org/10.1159/000353134

\section{EFFECTS OF COMBINED ANESTHESIA ON KIDNEY FUNCTION AFTER CORONARY ARTERY BYPASS GRAFT SURGERY WITH CARDIOPULMONARY BYPASS}

A. Kaunienė, A. Urbonaitė, T. Lenkutis, E. Širvinskas, M. Švagždienė

Key words: high epidural anesthesia, acute kidney injury. Summary

The aim of the study was to find out the effect of general anesthesia combined with high thoracic epidural (HEA) and only general anesthesia (GA) on renal function after coronary artery bypass graft surgery (CABGS) with cardiopulmonary bypass (CPB).
Material and methods. The study included patients (from 49 to 82 years), who had received CABGS with $\mathrm{CPB}$ at Lithuania university of health sciences Clinic of Cardiothoracic and vascular surgery during the period of October, 2014 to October, 2015. All patients were divided into two groups: first group (GA), which included patients who had received only GA (anaesthetics and intraveous opiates); and second group (HEA), which included patients who received HEA (local anaesthetic and GA anesthetics with intravenous opiates). Biochemical blood tests were run three times on each patient - before the surgery, one day after the surgery and five days after the surgery. The concentrations of blood serum creatinine and urea, which reflect kidney dysfunction, were evaluated during perioperative period.

Results of the study. The average concentration of pre - operative blood serum creatinine in HEA group was 93,3 $\pm 16 \mathrm{mmol}$ $/ 1$, in GA group $-95,3 \pm 23,5 \mathrm{mmol} / 1(\mathrm{p}>0,05)$. The average concentration of serum creatinine on first postoperative day in HEA group was 101,3 $\pm 19,3 \mathrm{mmol} / 1$, in GA group - 104,81 $\pm 37 \mathrm{mmol}$ $/ 1(\mathrm{p}<0,05)$. The average of blood serum creatinine concentration on the fifth postoperative day in HEA group was $97 \pm 14,3 \mathrm{mmol}$ $/ 1$, in GA group $-103,7 \pm 31,6 \mathrm{mmol} / 1(\mathrm{p}<0,05)$. The average pre - operative blood serum urea concentration in HEA group was $4,2 \pm 1,2 \mathrm{mmol} / \mathrm{l}$, in GA group 5,2 $\pm 1,7 \mathrm{mmol} / \mathrm{l}(\mathrm{p}>0,05)$. The average concentration of serum urea on first postoperative day in HEA group was 5,6 $\pm 1,8 \mathrm{mmol} / \mathrm{l}$, in GA group $6,2 \pm 2,0 \mathrm{mmol} / \mathrm{l}$. $(p>0,05)$. The average of blood serum urea concentration on the fifth postoperative day in HEA group was 4,7 $\pm 1,3 \mathrm{mmol} / 1$, in GA group $5,8 \pm 3 \mathrm{mmol} / \mathrm{l}(\mathrm{p}<0,05)$.

Findings of the study. When comparing the concentrations of blood serum creatinine and urea before the surgery, one day after the surgery and five days after the surgery, lower changes of both indicators are observed in the HEA group than in the GA group.

Correspondence to: agnesmilgyte92@gmail.com

Gauta 2016-05-10 